\title{
Mothers living with HIV: replacing breastfeeding by infant formula
}

\author{
Mães vivendo com HIV: a substituição do aleitamento por fórmula láctea infantil \\ Madres viviendo con VIH: la sustitución de la lactancia por una fórmula láctea infantil
}

Willyane de Andrade Alvarenga'
ORCID: 0000-0001-6114-8293
Lucila Castanheira Nascimento"
ORCID: 0000-0002-7900-7111

Camila Lima Leal"

ORCID: 0000-0002-4220-2298

Marcia Regina Cangiani Fabbro' ORCID: 0000-0003-2601-8818

Jamile Claro de Castro Bussadori'

ORCID: 0000-0002-3048-5593

Simone Santos e Silva Melo"' ORCID: 0000-0002-3050-4635

Denisse Cartagena-Ramos" ORCID: 0000-0002-8828-2190

Giselle Dupas'

ORCID: 0000-0001-9017-4474

'Universidade Federal de São Carlos. São Carlos, São Paulo, Brazil.

"Universidade de São Paulo, Escola de Enfermagem de Ribeirão Preto. Ribeirão Preto, São Paulo, Brazil.

"' Maternidade Dona Evangelina Rosa. Teresina, Piauí, Brazil.

How to cite this article: Alvarenga WA, Nascimento LC, Leal CL, Fabbro MRC, Bussadori JCC, Melo SSS, et al. Mothers living with HIV: replacing breastfeeding by infant formula. Rev Bras Enferm. 2019;72(5):1153-60. doi: http://dx.doi.org/10.1590/0034-7167-2017-0880

Corresponding Author:

Willyane de Andrade Alvarenga E-mail:willyalvarenga@hotmail.com

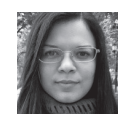

Submission: 12-14-2017

Approval: 04-13-2018

\section{ABSTRACT}

Objective: To explore factors that interact and shape the meaning and experience of mothers of HIV-exposed children in relation to replacing breastfeeding by infant formula. Method: A qualitative study was carried out with 23 mothers living with HIV, whose children were up to 18 months of age and under follow-up in a specialized care service. Symbolic Interactionism, semi-structured interviews and content analysis were adopted as theoretical framework. Results: The social symbols of breastfeeding, the (un)availability of the milk formula and the (lack of)support of health professionals influenced the mothers' experience with formula feeding. Social, cultural and economic constraints have proved capable of undermining the conditions necessary for the replacement of breastfeeding. Final considerations: The availability of infant formula, access to lactation inhibitor and quality of health services still represent challenges to eradicate new HIV infections in children.

Descriptors: HIV; Vertical Transmission of Infectious Disease; Breastfeeding; Infant Formula; Infant.

\section{RESUMO}

Objetivo: Explorar os fatores que interagem e moldam o significado e a experiência de mães de crianças expostas ao HIV em relação à substituição do aleitamento por fórmula láctea infantil. Método: Estudo qualitativo, com 23 mães vivendo com HIV, cujos filhos tinham até 18 meses de idade e estavam sob acompanhamento em serviço de assistência especializado. Foram adotados o Interacionismo Simbólico como referencial teórico, entrevistas semiestruturadas e análise de conteúdo. Resultados: Os símbolos sociais da amamentação, a (in)disponibilidade da fórmula láctea e o (des)apoio dos profissionais de saúde influenciaram a experiência das mães com a alimentação por fórmula láctea. Cerceamentos sociais, culturais e econômicos mostraram-se capazes de prejudicar as condições necessárias para a substituição do aleitamento materno. Considerações finais: A disponibilidade da fórmula láctea infantil, o acesso ao inibidor de lactação e a qualidade dos serviços de saúde ainda representam desafios para eliminar novas infecções pelo HIV em crianças.

Descritores: HIV; Transmissão Vertical de Doença Infecciosa; Aleitamento Materno; Fórmulas Infantis; Lactente.

\section{RESUMEN}

Objetivo: Explorar los factores que interactúan y moldean el significado y la experiencia de madres de niños expuestos al VIH en relación a la sustitución de la lactancia por una fórmula láctea infantil. Método: Estudio cualitativo, con 23 madres viviendo con $\mathrm{VIH}$, cuyos hijos tenían hasta 18 meses de edad y estaban bajo seguimiento en servicio de asistencia especializada. Se adoptaron el Interaccionismo Simbólico como referencial teórico, entrevistas semiestructuradas y el análisis de contenido. Resultados: Los símbolos sociales de la lactancia, la (in) disponibilidad de la fórmula láctea y el (des) apoyo de los profesionales de la salud influenciaron a la experiencia de las madres con la alimentación por una fórmula láctea. Los cercos sociales, culturales y económicos se mostraron capaces de perjudicar las condiciones necesarias para la sustitución de la lactancia materna. Consideraciones finales: La disponibilidad de la fórmula láctea infantil, el acceso al inhibidor de la lactancia y la calidad de los servicios de salud todavía representan desafíos para eliminar nuevas infecciones por el VIH en niños.

Descriptores: $\mathrm{VIH}$; Transmisión Vertical de Enfermedad Infecciosa; Lactancia Materna; Fórmulas Infantiles; Lactante. 


\section{INTRODUCTION}

Efforts to eradicate new HIV infections in children have been global. Currently $1,800,000$ children under the age of 15 are living with HIV worldwide, which represents less than $1 \%$ of all HIV-positive people ${ }^{(1)}$. In Brazil, despite a $42.7 \%$ reduction in mother-to-child HIV transmission rates in the last ten years, this category of exposure is important because of the increase in the number of pregnant women living with HIV in the last decade ${ }^{(2)}$. The decrease in HIV transmission from mother to child can be attributed to the availability of rapid HIV testing for pregnant women; the combination of antiretroviral therapy for mothers and newborns; the cesarean section birth, when indicated, and natural birth for women with undetectable viral load who made this option; and the counseling on non-breastfeeding (recommended in Brazil), which is replaced by infant formula ${ }^{(3)}$.

In Brazil, there are counseling of mothers living with HIV on non-breastfeeding and use of the infant formula available free of charge by the Brazilian Unified Health System (SUS - Sistema Único de Saúde) and guaranteed by GM/MoH Ordinance 2,313 of December 19, 2002 ${ }^{(4-5)}$, as breastfeeding poses a risk for HIV transmission. However, replacing breastfeeding with infant formula is still a challenge. Several national and international studies have pointed to difficult maternal experiences in the practice of infant formula, in which psychological suffering, the punitive feeling of not being able to breastfeed, the embarrassment and the physical and emotional pain are present ${ }^{(6-9)}$.

According to the World Health Organization, the success of substitute feeding to breastfeeding depends on the use of infant formula in an accessible, acceptable, viable, safe and sustainable way, that is, prepared in ideal conditions, through access to drinking water and adequate supply, cleanly, of sufficient quantity and frequency for the normal growth and development of children ${ }^{(10)}$. However, other factors influence the provision of safe milk formula feeding to children exposed to HIV and, therefore, may facilitate or intensify the difficulty of mothers handling this type of feeding. It is known that the sociocultural aspects that encourage breastfeeding impact women who are unable to breastfeed ${ }^{(6)}$. However, there are few studies on the subject in countries that have free and universal access to antiretroviral therapy ${ }^{(7)}$, especially in Brazil ${ }^{(11)}$, which presents a great economic, demographic and epidemiological disparity in relation to HIV. This points to the need for more research, especially in the face of the questioning of mothers living with HIV about the possibility of breastfeeding their children or of situations where they eventually choose to breastfeed them in countries where the recommendation is contrary ${ }^{(12-13)}$. Knowing how HIV-infected mothers experience this situation (who should not breastfeed and have to deal with substitute feeding in countries that adopt this recommendation) will provide insight into the trajectory of difficulties related to safe feeding of the child. Specific interventions need to be discussed based on the realities encountered ${ }^{(14)}$ and on the factors that hinder this maternal experience.

The interactionist perspective used in this study, which seeks to know human behavior through the study of the phenomenon in the context of social interactions, confers to this research a social dimension that allows describing it not only based on how people think, act and behave, but also, considering social structures that are reflected in the mothers' experiences ${ }^{(15-16)}$.

\section{OBJECTIVE}

To explore factors that interact and shape the meaning and experience of HIV-exposed children's mothers in relation to replacing breastfeeding by infant formula.

\section{METHOD}

\section{Ethical aspects}

The research followed all ethical precepts in force in Brazil for its conduction and obtained approval from the Research Ethics Committee of the Universidade Federal de São Carlos. The guidelines of Resolution 196, of 1996, of the National Health Council (Conselho Nacional de Saúde), in force at the time of the elaboration and execution of the research project, were respected. All participants entered the study after signing the Informed Consent Form.

\section{Type of study}

It is a descriptive study with a qualitative approach, in which Symbolic Interactionism (SI) was adopted as a theoretical perspective to examine the phenomenon in question, since such an approach comprises the actor in the social situation and its action as a result of the continuous interaction with others and with the situation that lives or interpret ${ }^{(15)}$. The central concepts of SI used in this study were the symbol and social interaction, which are interrelated and, together, are precipitated in the social process. As the person, as a social being, incorporates the attitudes of others through the process of language, people begin to assimilate these values as their own, that is, he becomes the other. In this way, it adopts the role of the other, and its values come from this social process. There are significant symbols in human behavior, so that gestures have meanings, present objectively in the social situation. Thus, meaning arises from the social process of communication and it is possible to understand and interpret the action of the person through the understanding of the symbols, because people act according to the meaning they attributes to things ${ }^{(16)}$.

\section{Study setting}

The scenario of the study was a Specialized Assistance Service (SAE - Serviço de Assistência Especializada) in HIV/AIDS, located in a municipality in Piauí State, responsible for the follow-up of the majority of children born to HIV-infected mothers in this state and other surrounding areas.

\section{Data source}

Twenty-three mothers diagnosed with HIV were intentionally selected through the following eligibility criteria: age greater than 18 years, HIV-positive diagnosis, and mothering of children up to 18 months of age under follow-up in an HIV/AIDS's SAE. 


\section{Collection and organization of data}

Single and individual semi-structured interviews were conducted from January to May 2013 by the principal investigator, in a private room provided by the SAE for this purpose, at the moment when the mothers waited for the child's medical care. In the first contact with the participants, the interview was invited to the study and, through acceptance, the interview was conducted with the purpose of collecting data to characterize them. Subsequently, the mothers were invited to describe how they had experienced the substitutive feeding of the child. New questions emerged during the flow of the interviews in order to describe in detail the factors that influenced the experience of non-breastfeeding and substitutive feeding. Field notes were included during and after each interview. The mean time was 50 minutes, and the participation limit occurred due to the saturation of the data, evaluated by the comparative method for saturation of the subjects, through multiple comparisons ${ }^{(17)}$. Two mothers refused to participate in the study due to unavailability of time.

\section{Data analysis}

The interviews were audio recorded, transcribed in full and submitted to Qualitative Content Analysis ${ }^{(18)}$. The phases were preparation, organization and reporting of results and the codes were generated in an inductive way ${ }^{(18)}$. Transcripts of interviews and field notes were read carefully. Next, we selected the units of meaning according to the sense nuclei. The choice of certain units of analysis occurred according to the purpose of the study and the theoretical framework. The interactionist perspective allowed the approximation with the meanings, which are reflected in the experience of mothers living with HIV in relation to the substitution of breastfeeding. Based on the understanding of the meanings present in the discourse, elements were both involved in the social process and incorporated by the mother. Thus, the results are presented in two categories: "The social symbols of breastfeeding" and "(Un)availability of artificial formula and (lack of)support of health professionals". Both illustrate the factors arising from the context of social interaction that interact and shape the experience of mothers.

The analysis was carried out by two researchers together and the other authors followed the whole development of the study, in order to ensure the methodological rigor and the accuracy of the data interpretation. Data reliability criteria were carefully considered in each phase of the study ${ }^{(19)}$. We chose to discuss differences between authors, in order to maintain the quality and trustworthiness of the analyses. In the presentation of the excerpts from the mothers' discourses, the letter $M$ was used, followed by the order number of the study, in order to preserve the anonymity of the participants.

\section{RESULTS}

Mothers were between 20 and 38 years (mean age of 28 years); $65 \%(n=15)$ had more than nine years of schooling, were married or lived in a stable union. Seven of them lived the second experience of a child with vertical exposure to HIV. All of them found that they were HIV-positive during one of the pregnancies and performed the prenatal care of the child who was being followed up at the SAE at the time of data collection in this research. Only one mother reported having a child diagnosed with HIV because she was not HIV-positive in the previous pregnancy.

The results discuss the factors that influence the mothers' experience of breast milk substitute feeding to the HIV exposed child and were presented through the elaboration of two categories that describe the phenomenon: "The social symbols of breastfeeding" and "(Un)availability of artificial formula and (lack of)support of health professionals".

\section{The social symbols of breastfeeding}

Mothers considered not breastfeeding the most difficult moment of the path of care for children exposed to HIV. The report of suffering in the face of this impossibility was unanimous among those who had previously breastfed another child. The social figure of the mother breastfeeding was understood as a dream interpellated by the moral action of protecting the child from HIV infection. However, they alleviated the emotional impact of not being able to breastfeed with the support of some family members and through the physical withdrawal of the child.

It is my dream to breastfeed, but I couldn't! There was a time he [son] was very small and I put him on my lap and was about to put my breasts out to give it to him. So I remembered that I couldn't give. I was wishing to breastfeed, my son cried and I said to myself: I can't! I left him crying because I didn't like to see. I would prefer to move away. (M9)

I feel like breastfeeding, but I can't. To pass the will I walk, I give her [daughter] to my mother to hold, sometimes my sister, take her so I can go to walk. (M4)

Mothers perceived the formula offering as an imposition:

Because I couldn't breastfeed, I was forced to give milk. (M7)

Social discourses and symbolisms about breastfeeding seem to influence maternal suffering. The discourse that "breast milk" is the best food for the baby was reproduced by the participants, which increased sadness and influenced the provision of a diet considered by them to be more appropriate for the child. In this sense, some have reported adding farinaceous to the infant formula because they considered it insufficient to provide it alone $(n=2)$ and others $(n=2)$ reported allowing another nurse to breastfeed her child.

He drank milk every three hours, but I shortened that time, and yet, he was crying. So I started adding "dough" [farinaceous]. If I breastfeed, I'd be giving only breast milk until six months, because with my other son was like that. Breast milk was enough. I believe that this artificial milk is weak. (M10)

I gave my niece to breastfeed him a couple of times, because she had a lot of milk. I cried when I saw her breastfeeding him [son], and so did she. She knows I have HIV; she took pity on me and so she did it. (M6) 
The meanings around breastfeeding caused the participants to question also about the mother-child bond, since they believed that breastfeeding "unites the mother more to the child" and associated the artificial feeding with difficulties of interaction and possible loss in the development of the child.

I didn't think I would like her as much as I liked others. I was afraid she would not suck and not be like the other children. (M12)

The act of breastfeeding connects the mother and the child. (M11)

I feel like I've made a stupid thing in my life and, because of me, she [daughter] doesn't suck at the breast. I think my daughter is not being a healthy girl. I feel guilty [cry]. (M4)

The constant questioning of other people about the reason for the child not being breastfed also potentiated the negative perception about this experience, which contributed to intensify reactions of sadness, guilt and anger of themselves. Mothers omitted the real reason for not breastfeeding, fearing prejudice and judgments stemming from the social meanings about breastfeeding and HIV-positive diagnosis.

When people saw, they asked: 'Does not he suck at the breast?' I would answer: - no, he never did. 'Really? And is such a healthy child!' They always asked why, and I said that my breast has dried up. I didn't tell the truth because people have a lot of prejudice. (M7)

\section{(Un)availability of artificial formula and (lack of)support of health professionals}

Other factors have made substitute feeding even more challenging and distressing for mothers. Lack of professional counseling/ support and health service weaknesses, such as unavailability of infant milk formulas and/or exceeded validity periods, have influenced the way the participants attributed meaning to the situation, and how they faced it. Understanding the reason for not breastfeeding was important for mothers, who prioritized the protection of the child, even in the face of the desire to breastfeed and social influences. Still in the maternity, some reported lack of clarification on the reason for the interruption and guidelines on how to deal with this situation, and therefore one of them said she had breastfed her baby because she could not afford the infant formula. Although the free milk formula is guaranteed by public policy to all children exposed to HIV, there was no delivery of the formula to this mother in the maternity ward:

They did not advise me at all, except that I couldn't breastfeed and that was it. To make the situation worse, they put me in a meeting of motivation to breastfeed, which I couldn't have participated. I was angry! (M20)

When my son was born, they collected my blood at the hospital and didn't direct me right about what I had. They just asked me not to breastfeed, but when they went out, I would breastfeed. [...] I had been out of hospital for three days and I continued to breastfeed, I was not able to buy milk. After eight days, in a home visit of the nurse, was that I knew what I had. (M18)
Most of the mothers were discouraged from breastfeeding and received a chemical inhibitor of lactation. Four mothers received the chemical inhibitor plus the physical inhibitor, such as breast wrapping, and another reported no maternal lactation inhibitor. Some participants developed mastitis due to interruption of breastfeeding:

On the second day I was in the maternity ward I was given medication to dry my breasts and they still tied a band with gauze on my breast not to leak, even when it dried. (M8)

I still have milk [child one month old]; the breasts begin to fill. They haven't done anything in the maternity ward. I've always had milk! (M9)

Because she could not offer her milk to the child, according to Brazilian recommendations, the mother replaced it by the infant formula provided free of charge in the maternity and SAE. The receipt of the free formula was seen as a great help in the face of the socioeconomic difficulties of some families. However, there were cases in which the child did not receive the infant formula at the time of maternity leave $(n=7)$ and the mother had difficulty acquiring it due to early interruption of delivery by SAE or unavailability in the service $(n=12)$. The need to buy the infant formula, due to the absence of free supply, represented a high financial cost and required the re-allocation of the monthly family budget or the support of family members.

Ileft the maternity ward with the milk. I received eight cans. After one month we came here [SAE] for an appointment and we received again another eight cans. There in the maternity ward, they taught me how I had to do to prepare it. They wrote down everything in a piece of paper. (M22)

There are two months I didn't get, because here [SAE] at the pharmacy there wasn't. I asked the doctor if I could give another type of milk, cheaper. [...] we think a lot of "bullshit", and when you don't have money to buy, what can we do? (M13)

He has been following up for three months and we have not received the formula yet. They say it's missing. We received family help to buy. (M17)

The lack of support from the health service has increased the suffering of mothers because they feel helpless and sometimes because of this lack of commitment to the optimal diet of their children, due to the provision of formula with an exceeded validity $(n=2)$, for example. In addition, one of the children had lactose intolerance and had to feed on another type of milk, not provided by the service. In this case, the family was deprived of the resources to offer an alternative feeding due to the high cost.

The first time we received the milk given by the maternity ward and they were all expired. (M3)

She [nutritionist] suspended this milk and I had to buy soy milk because he [son] could be lactose intolerant. It is very difficult to buy, because it is very expensive. (M19) 
The preparation and the offering of the food to the child at home were carried out according to the counseling received during the pregnancy-puerperal period. However, some mothers, because they did not receive prior professional counseling in the maternity ward, prepared the milk formula according to the recommendations on the product label and sought to reproduce the hospital routine by offering it $(n=6)$. Those guided at hospital discharge followed the recommendations and fed their children at three-hour intervals. Participants also reported using bottles, offering teas and adding water between feeds, although they had not received such guidelines in the hospital.

It was always me who gave the milk in the maternity ward. They only said: "Here's the baby's milk!". At home, I prepared as directed on the can's label, but they didn't tell me in the maternity ward how I had to do it. I gave when she cried. Later I learned that the amount I put was wrong. (M21)

They didn't advise that I had to give water, but I give, because he doesn't suck at the breast. At hospital, they gave milk every three hours and at home I continued. Although he received milk in the little glass at the hospital, at home, I give him the baby bottle, because they didn't say anything about it. (M16)

\section{DISCUSSION}

The main factors that influenced the experience of mothers living with HIV in relation to the substitutive feeding of their children by infant formula were the social symbols of breastfeeding, the (un)availability of the artificial formula and the (lack of) support of health professionals. These results indicate elements from the social process capable of interfering in the experience and behavior of the mothers before the substitutive feeding of the child. This confers a macrostructural character to the experience of infant feeding, which should be seen as a psychosocial issue, considering the social and cultural positioning of motherhood and living with HIV(6). For Symbolic Interactionism, symbols and meanings are socially constructed and mutually apprehended in social interactions, so that the person acts according to the meaning he/she assigns to things, evidencing the power of relationships and social structures over individual experience ${ }^{(15)}$. A meta-synthesis of qualitative studies shows that from the gestation, the experience of women living with HIV is socially mediated ${ }^{(20)}$.

The results show that mothers considered breastfeeding an important aspect for the realization of motherhood, and the fact that they could not breastfeed their children generated sadness, guilt and insecurity. The way they perceive and face nonbreastfeeding during HIV is related to the social meanings that permeate this practice. These findings are supported by another study that shows how not breastfeeding interferes with the social identity of being a mother, generating guilt for not fulfilling this socially expected role and also for the feeling of placing the child at risk for not offering the best food, as reported in the media and public health services ${ }^{(6)}$.

Reports of situations in which the mother has not been clarified about her diagnosis and allowed cross-breastfeeding contradict the one recommended by the Brazilian Ministry of Health, which contraindicates breastfeeding, mixed breastfeeding or cross-breastfeeding and assures the mother the right to receive formula infants up to the child's sixth month of life ${ }^{(5)}$. In some Brazilian states, this distribution occurs until the 12th month, as established in the scenario of this research, although this is not always fulfilled. The right to receive infant formula free of charge has not been assured to all children exposed to HIV in this study, as there were reports of mothers who did not receive infant formula for unavailability in the health service; because the expiry date is exceeded; need to provide special milk formula for the child with lactose intolerance. All of these situations compromise the success of providing adequate formula feed to children exposed to HIV and undermine prevention measures for mother-to-child transmission of HIV.

Results of other research in the national context point to the lack of structuring of health services to provide free infant formula $^{(21-22)}$ and the need to discuss aspects that limit this access ${ }^{(7)}$. It is a problematic scenario in countries that decide to avoid any type of breastfeeding for children born to HIV-positive mothers, since this decision is based on international recommendations and considerations about the socioeconomic and cultural context of the populations served by maternal and child health services, as well as the availability and quality of health services ${ }^{(5)}$.

The results of the present study show that some children did not receive adequate nutrition for some main reasons such as the belief that the formula does not meet their nutritional needs, the lack of professional counseling regarding the preparation and the lack of free or financial access to the formula. This fact clearly expresses that infant feeding cannot be solely responsible for health strategies, since it is associated with social and economic determinants of health. Other studies describe similar results: mothers who chose to offer whole cow's milk to infants, which leads to nutritional impairment ${ }^{(23)}$, or who offered foods compatible with their financial conditions after the suspension of free milk distribution ${ }^{(24)}$.

The results also show that the lack of guidelines on the transmission of the virus through breastfeeding, the main reason for not being able to breastfeed, and how to prepare and offer the milk formula to the child influenced infant feeding. These results point to the precariousness of the information provided by nurses and medical staff to mothers with HIV in both pregnancy and postpartum period and later, as well as the lack of preparation to communicate the diagnosis to these women. A similar situation was identified in other Brazilian studies, in which mothers living with HIV prepared the artificial feeding according to the guidelines of the product or were not even sure how to prepare it ${ }^{(11,25)}$. One of the reasons is the deficiency in the guidelines received and the lack of understanding of these recommendations ${ }^{(25)}$. In this sense, the results of the present research show that mothers are not being adequately guided to the specific skills necessary to prepare and offer the infant formula to the child.

A Canadian research has considered as disquieting the poor communication of health professionals as well as how infant feeding in the context of HIV is conducted, especially without the necessary care regarding the social and emotional aspects of the mother ${ }^{(6)}$. Studies have shown that effective guidelines for women with HIV should start before pregnancy even to address aspects of reproductive health and HIV transmission ${ }^{(26)}$, and that it has been a challenge to overcome health system weaknesses and 
barriers to reduce transmission of this virus via breastfeeding ${ }^{(12)}$. Even in resource-limited settings, where exclusive breastfeeding is strongly encouraged up to six months, the psychosocial and economic barriers that impact infant feeding are perceptible ${ }^{(27)}$.

It should be emphasized that health professionals have an important role in counseling mothers regarding non-breastfeeding ${ }^{(7)}$, in disseminating information on risk factors for HIV transmission ${ }^{(11)}$, in psychological care according to the method of inhibition to be used $^{(9)}$, in the preparation and supply of infant formula ${ }^{(11)}$. They must also offer emotional and humanized support so that these mothers feel supported and secure at that time ${ }^{(9)}$. Including their partners, especially in the guidelines for prevention of motherto-child transmission of HIV, is another key aspect in eradicating new HIV infections in children and keeping their mothers alive ${ }^{(28)}$. It is worth highlighting that failures in this practice impose a substantial risk, since knowledge about the disease and the receipt of infant formula are important both for the follow-up of preventive measures for mother-to-child transmission of HIV and for child development. Providing safe alternatives to breastfeeding and promoting comprehensive health education can reduce the risk of mother-to-child transmission of HIV in developing countries ${ }^{(13)}$.

The physical withdrawal of the child was a measure of coping cited by the mothers of the present study in the face of the suffering caused by not being able to breastfeed, which was potentialized by the context of stigma and inefficient support of the health service. However, perceiving the non-breastfeeding as a way to protect the child emerged as a way to re-signify this suffering, an aspect also observed in other studies ${ }^{(7,9,29)}$. From the gestation, the mother with HIV brings with it a trajectory of guilt and anxiety for the possibility of transmitting HIV to the child, the frustration of not breastfeeding and the doubts related to the lack of knowledge ${ }^{(20)}$. Feeling guilty for not breastfeeding, social isolation due to HIV stigma and lack of clarification regarding infant feeding practices are factors pointed out in researches as contributors to an experience of suffering in HIV-positive mothers, to decrease mother-child attachment, to mistakes and a negative perception of being a mother ${ }^{(6,30)}$. These effects have repercussions not only on the health of the child, but also on the family in the long term, since there is a negative association of the stress of mothers living with HIV with family dynamics, aspects of cohesion, routines and family communication ${ }^{(31)}$.

\section{Study limitations}

Participants in the study were mothers living with HIV whose children were being followed up at a specialized public service for the care of people with HIV/AIDS, thus not including those who did not attend or were accompanied in other public services and private practices. Although the experiences reported by them regarding substitutive feeding cannot represent all mothers living with HIV in the regional or national setting, the results contribute to increase knowledge in this area, including the lack of studies of this nature since they show an extended perspective to subsidize best practices to those who will need to deal with the substitutive feeding of their children.

The development of new research on the experiences of mothers living with HIV in other Brazilian contexts and in countries where there is also a free distribution of food formula is recommended. Likewise, studies focusing on the socioeconomic and cultural determinants influencing infant formula may help to develop effective measures to address barriers to the use of the milk formula and the non-breastfeeding stigma associated with HIV, spaces where breastfeeding is a symbol of good motherhood.

\section{Contributions of the study in the sectors of Nursing and Public Policies}

The results of the present study allow us to explore aspects that influence the experience of mothers living with HIV in relation to substitutive feeding of breastfeeding, namely: the relevance of institutions and social contexts, such as symbols of breastfeeding, stigma of living with HIV, professional counseling and formula offering. They also allow us to explore actions and behaviors adopted/adapted by the mothers for a better experience in this context. For the participants of this study, experience with infant feeding during the lifetime of HIV was not exempt from social, cultural and economic constraints, which proved capable of undermining the conditions necessary for an acceptable, safe, viable, accessible and sustainable diet by infant formula.

Despite recent advances in the prevention of HIV transmission from mother to child in Brazil, the results show weaknesses in compliance with recommendations on non-breastfeeding, which indicates the need to review some aspects to increase the capacity to implement this prevention strategy, in order to prevent new HIV infections in children through breastfeeding. Facilitating the availability of infant formula, expanding access and improving the quality of health care, especially in issues involving health education, are still challenges to adequate infant feeding in the context of HIV.

Strengthening the health system, especially nursing, is fundamental in this context, as the results of this study refer to the need to excel in the quality of care provided. Providing emotional and informational support, as well as nursing care based on the specific needs and situations of the family, social and cultural context of mothers and children exposed to HIV, enhances the capacity of the health system to respond positively to the prevention of mother-to-child transmission of HIV.

\section{FINAL CONSIDERATIONS}

For the mother, not being able to breastfeed the baby due to HIV is a complex and difficult experience. The present study revealed socio-structural influences and processes that may improve the understanding of this maternal experience, where there is a need for replacement of breastfeeding by infant formula. The social symbols of breastfeeding, the (un)availability of the artificial formula and the (lack of)support of health professionals were the main categories of this study, which report the factors that influence the mothers' experience with replacing breast milk feeding for the child exposed to HIV.

It is necessary to transcend the issue of technical skills in the management of non-breastfeeding and seek to transform care practices through the recognition of maternal suffering, the influence of social, cultural and economic structures of the context in which they live and of the value of educational and follow-up 
actions of mothers. To privilege humanized relationships between professional and mother makes it possible to share experiences and favors peer dialogue on the uniqueness of non-breastfeeding, child care and the socio-cultural context. There is also the opportunity to explore new paths in order to favor the experience of mothers in offering a safe diet with infant formula.

\section{FUNDING}

This study was financed by the Fundação de Amparo à Pesquisa do Estado de São Paulo - FAPESP (12/21001-2) and in part by the Coordenação de Aperfeiçoamento de Pessoal de Nível Superior Brasil (CAPES) - Finance Code 001.

\section{REFERENCES}

1. Joint United Nations Program on HIV/AIDS (UNAIDS). Global report: Get on the Fast-Track: the life-cycle approach to HIV. Geneva, Switzerland: UNAIDS; 2016.

2. Ministério da Saúde (BR), Secretaria de Vigilância em Saúde, Departamento de Vigilância, Prevenção e Controle das Infecções Sexualmente Transmissíveis, do HIV/Aids e das Hepatites Virais. Boletim epidemiológico HIV/AIDS. Ano V-1. Brasília (DF): MS; 2016.

3. Ministério da Saúde (BR). Secretaria de Vigilância em Saúde. Departamento de DST, Aids e Hepatites Virais. Protocolo clínico e diretrizes terapêuticas para prevenção da transmissão vertical de HIV, Sífilis e Hepatites Virais. Brasília (DF): MS; 2015.

4. Ministério da Saúde (BR). Secretaria de Vigilância em Saúde. Departamento de Vigilância, Prevenção e Controle das Infecções Sexualmente Transmissíveis, do HIV/Aids e das Hepatites Virais. Protocolo Clínico e Diretrizes Terapêuticas para o manejo da infecção pelo HIV em crianças e adolescentes. Brasília (DF): MS; 2017.

5. Ministério da Saúde (BR). Gabinete do Ministro. Portaria № 2313/GM em 19 de dezembro de 2002[Internet]. Diário da União. 2002 [cited 2018 Mar 14];44-4. Available from: http://pesquisa.bvs.br/brasil/resource/pt/crt-4257\#.WqkY8dE1W4A

6. Greene S, Ion A, Elston D, Kwaramba G, Smith S, Carvalhal A, et al. "Why Aren't You Breastfeeding?": how mothers living with hiv talk about infant feeding in a "Breast Is Best" world. Health Care Women Int. 2015;36(8):883-901. doi: https://doi.org/10.1080/07399332.2014.888720

7. MacCarthy S, Rasanathan JJK, Nunn A, Dourado I. "I did not feel like a mother": the success and remaining challenges to exclusive formula feeding among HIV-positive women in Brazil. AIDS Care. 2013;25(6):726-31. doi: https://doi.org/10.1080/09540121.2013.793274

8. Jerome JS, Galvao MT, Lindau ST. Brazilian mothers with HIV: experiences with diagnosis and treatment in a human rights based health care system. AIDS Care. 2012;24(4):491-5. doi: https://doi.org/10.1080/09540121.2011.613906

9. Frigo J, Zocche DAA, Silveira S, Marin SM, Rodriguez MJH, Ledra FF. Perceptions of the bearers of HIV/AIDS before the inability to breastfeeding. Rev Pesqui: Cuid Fundam[Internet]. 2014[cited 2017 Nov 16];6(2):627-36. Available from: http://www.seer.unirio.br/index. php/cuidadofundamental/article/view/3091

10. World Health Organization-WHO. Guideline Uptades on HIV and infant feeding, 2016: the duration of breastfeeding and support from health services to improve feeding practices among mothers living with HIV. Geneva, Switzerland:WHO; 2016.

11. Freitas JG, Barroso LM, Galvão MT. Maternal ability to take care of children exposed to HIV. Rev Latino-Am Enfermagem[Internet]. 2013[cited 2017 Nov 16];21(4):964-72. Available from: http://www.scielo.br/pdf/rlae/v21n4/0104-1169-rlae-21-04-0964.pdf

12. Rollins N, Coovadia HM. Breastfeeding and HIV transmission in the developing world: past, present, future. Curr Opin HIV AIDS. 2013;8(5):467-73. doi: https://doi.org/10.1097/COH.0b013e3283632ba2

13. Levison J, Weber S, Cohan D. Breastfeeding and HIV-Infected Women in the United States: Harm Reduction Counseling Strategies. Clin Infect Dis. 2014;59(2):304-9. doi: https://doi.org/10.1093/cid/ciu272

14. Cerda R, Perez F, Domingues RM, Luz PM, Grinsztejn B, Veloso VG, et al. Prenatal Transmission of Syphilis and Human Immunodeficiency Virus in Brazil: achieving regional targets for elimination. Open Forum Infect Dis. 2015;2(2):ofv073. doi: https://doi.org/10.1093/ofid/ofv073

15. Charon JM. Symbolic interacionism: an introduction, an interpretation, an integration. 10 ed. New Jersey, NJ: Prentice-Hall; 2009.

16. Mead GH. Espíritu, persona y sociedad: desde el punto de vista del conductismo social. Barcelona: Paidos, 1982.

17. Constatinou CS, Georgiou M, Perdikogianni M. A comparative method for themes saturation (CoMeTs) in qualitative interviews. Qualit Res. 2017;1-18. doi: https://doi.org/10.1177/1468794116686650

18. Elo S, Kyngäs H. The qualitative content analysis process. J Adv Nurs. 2008;62(1):107-15. doi: https://doi. org/10.1111/j.1365-2648.2007.04569.x

19. Elo S, Kääriäinen M, Kanste O, Pölkki T, Utriainen K, Kyngäs H. Qualitative content analysis: a focus on trustworthiness. SAGE Open. 2014;4(1):1-10. doi: https://doi.org/10.1177/2158244014522633

20. Leyva-Moral JM, Piscoya-Angeles PN, Edwards JE, Palmieri PA. The Experience of Pregnancy in Women Living With HIV: a meta-synthesis of qualitative evidence. J Assoc Nurses AIDS Care. 2017;28(4):587-602. doi: https://doi.org/10.1016/j.jana.2017.04.002

21. Santos EM, Reis AC, Westman S, Alves RG. Avaliação do grau de implantação do programa de controle da transmissão vertical do HIV em maternidades do "Projeto Nascer". Epidemiol Serv Saúde[Internet]. 2010[cited 2017 Nov 16];19(3):257-69. Available from: http://scielo.iec. gov.br/pdf/ess/v19n3/v19n3a08.pdf 
22. Machado MMT, Galvão MTG, Lindsay AC, Cunha AJLA, Leite AJM, Leite RD. Condições sociodemográficas de crianças de zero a dois anos filhas de mães com HIV/Aids, Fortaleza, CE, Brasil. Rev Bras Saúde Matern Infant[Internet]. 2010[cited 2017 Nov 16];10(3):377-82.Available from: http://www.scielo.br/pdf/rbsmi/v10n3/v10n3a11.pdf.

23. Morais MB, Cardoso AL, Lazarini T, Mosquera EMB, Mallozi MC. Habits and attitudes of mothers of infants in relation to breastfeeding and artificial feeding in 11 brazilian cities. Rev Paul Pediatr[Internet]. 2017[cited 2017 Nov 16];35(1):39-45. Available from: http://www.scielo.br/ pdf/rpp/v35n1/en_1984-0462-rpp-35-01-00039.pdf

24. Silva MR, Alvarenga WA, Dupas G. Experiência do cuidador no tratamento preventivo da criança exposta ao Vírus da Imunodeficiência Humana. Rev Rene[Internet]. 2014[cited 2017 Nov 16];15(5):743-52. Available from: http://www.redalyc.org/articulo.oa?id=324032944003

25. Barroso LMM, Galvão MTG, Cavalcante RM, Freitas JG. Cuidado materno aos filhos nascidos expostos ao HIV/AIDS. Rev Rene[Internet]. 2009[cited 2017 Nov 16];10(4):155-64. Available from: http://periodicos.ufc.br/rene/article/view/4873

26. Kastner J, Matthews LT, Flavia N, Bajunirwe F, Erikson S, Berry NS, et al. Antiretroviral Therapy helps HIV-Positive women navigate social expectations for and clinical recommendations against childbearing in Uganda. AIDS Res Treat. 2014;2014:626120. doi: https://doi. org/10.1155/2014/626120

27. Mataya R, Mathanga D, Chinkhumba J, Chibwana A, Chikaphupha K, Cardiello J. A qualitative study exploring attitudes and perceptions of HIV positive women who stopped breastfeeding at six months to prevent transmission of HIV to their children. Malawi Med J[Internet]. 2013[cited 2017 Nov 16];25(1):15-9. Available from: https://www.ncbi.nlm.nih.gov/pmc/articles/pmid/23717750/

28. Langendorf TF, Padoin SMM, Paula CC, Souza IEO, Terra MG, Silva CB. Cotidiano ser-casal: profilaxia da transmissão vertical HIV. EsC Anna Nery[Internet]. 2015[cited 2017 Nov 16];19(2):259-64. doi: https://doi.org/10.5935/1414-8145.20150034

29. Gonçalves VF, Teixeira DQ, Oliveira PF, Sousa TH. HIV-seropositive women: understanding, feelings and experience before motherhood. Rev Bras Promoc Saude[Internet]. 2013[cited 2017 Nov 16];26(2):281-9. Available from: http://www.bioline.org.br/abstract?bh13070

30. Galvão MTG, Paiva SS. Vivências para o enfrentamento do HIV entre mulheres infectadas pelo vírus. Rev Bras Enferm[Internet]. 2011[cited 2017 Nov 16];64(6):1022-7. Available from: http://www.scielo.br/pdf/reben/v64n6/v64n6a06.pdf

31. Schulte MT, Armistead L, Marelich WD, Payne DL, Goodrum NM, Murphy DA. Maternal parenting stress and child perception of family functioning among families affected by HIV. J Assoc Nurses AIDS Care. 2017;28(5):784-94. doi: https://doi.org/10.1016/j.jana.2017.05.004 